\title{
COMMENTARY
}

\section{When the dust settles: what did we learn from the bexarotene discussion?}

\author{
Ina Tesseur ${ }^{1,2}$ and Bart De Strooper ${ }^{1,2^{*}}$
}

\begin{abstract}
With 27 million people affected by Alzheimer's disease (AD), any proposal of a novel avenue for drug development is hot news. When Cramer and colleagues proposed last year that they could tackle $A D$ pathology in an $A D$ mouse model with bexarotene, a drug already in use in the clinic for other diseases, the news was covered worldwide by the popular press. Apolipoprotein E4 is the strongest genetic risk factor for $A D$ and bexarotene appeared to exert spectacular effects on AD pathology when tested in APP/PS1 transgenic mice. One year later the slumbering discussion on the use of bexarotene in $A D$ exploded in a flurry of papers. Four papers question the initial optimistic claims, while two others can only partially support the original work. We summarize here the available data and try to make sense out of the controversy. The major question is what we can learn from the experiments and what these studies imply for the further development of bexarotene in the clinic.
\end{abstract}

Apolipoprotein E4 (apoE4) is the most important genetic risk factor for sporadic Alzheimer's disease (AD) and therefore an interesting drug target per se. Despite numerous studies trying to address by which mechanism apoE4 affects the risk for $\mathrm{AD}$, a definitive answer has not yet emerged. Both the ideas that apoE4 accelerates and fails to protect against disease have been proposed [1-3]. These opposite views have important implications when devising therapeutic strategies for $\mathrm{AD}$. If apoE4 accelerates the disease, then inhibition of apoE4, or the toxic pathways in which it plays a role, would be required. Practically this would imply, for instance,

\footnotetext{
* Correspondence: bart.destrooper@cme.vib-kuleuven.be

${ }^{1}$ VIB Center for the Biology of Disease, Herestraat 49, box 602, Leuven BE3000, Belgium

${ }^{2}$ Center for Human Genetics and Institute of Neuroscience and Disease (LIND), KU Leuven and Universitaire Ziekenhuizen, Leuven B-3000, Belgium
}

inhibiting the cleavage of apoE4 into toxic fragments or blocking apoE4's effects on amyloid beta (A $\beta)$ oligomerization [2,3]. If apoE4 fails to protect against $\mathrm{AD}$, however, then potentiation of the function of wildtype apoE would be desirable - for instance, by generating apoE3 mimetics, which could improve the brain clearance of $\mathrm{A} \beta$ that may be affected in APOE4 carriers $[1,3]$.

The paper by Cramer and colleagues [4] fitted nicely into the second strategy and showed that upregulation of apoE and apoE-related pathways could improve amyloid plaque accumulation and behavior in a mouse model of AD. Moreover, it demonstrated that this was possible by administering the drug bexarotene, which was already approved by the US Food and Drug Administration (FDA) for use in humans [5]. The excitement that this possibility could rapidly become tested in real, sporadic AD patients propelled the publication into the popular press.

Bexarotene is a retinoid X receptor (RXR) agonist that induces transcription of the ATP-binding cassette transporter gene A1 (ABCA1), as well as apoE and other genes involved in lipid metabolism through obligatory heterodimerization of RXR with liver $\mathrm{X}$ receptor and peroxisome proliferator-activated receptor- $\gamma$. As a result, bexarotene induces accumulation of triglycerides in vivo, which can result in liver steatosis and hypertriglyceridemia [6]. ApoE and ABCA1 are expressed in the central nervous system and in the periphery and measuring their expression should give a good indication of target engagement by bexarotene in both the central nervous system and the periphery.

Given the spectacular results of Cramer and colleagues [4], it is not surprising that many research groups worldwide attempted to replicate the original study. The data are summarized in Table 1. The major claim of the original study was a rapid clearance of $A \beta$ deposits from the brains of AD model mice [4]. This claim could not be confirmed in five independent follow-up studies [7-11], despite target engagement. Interestingly, and in 
Table 1 Overview of drug formulation and experimental outcomes of Alzheimer's disease model mice treated with Bexarotene

\begin{tabular}{|c|c|c|c|c|c|c|c|c|}
\hline \multirow[b]{2}{*}{$\begin{array}{l}\text { Research } \\
\text { group }\end{array}$} & \multirow[b]{2}{*}{$\begin{array}{l}\text { Drug } \\
\text { formulation }\end{array}$} & \multirow[b]{2}{*}{$\begin{array}{l}\text { Duration } \\
\text { of } \\
\text { treatment }\end{array}$} & \multicolumn{6}{|c|}{ Experimental claims } \\
\hline & & & $\begin{array}{l}\text { Target } \\
\text { engagement } \\
\text { (ApoE/ } \\
\text { ABCA1) }\end{array}$ & $\begin{array}{l}\text { Decrease of } \\
\text { soluble } A \beta\end{array}$ & $\begin{array}{l}\text { Clearance of } \\
\text { deposited } A \beta / \\
\text { plaques }\end{array}$ & $\begin{array}{l}\text { Behavioral } \\
\text { improvements }\end{array}$ & $\begin{array}{l}\text { In vivo } \\
\text { microglia } \\
\text { activation }\end{array}$ & $\begin{array}{l}\text { Mechanism- } \\
\text { based } \\
\text { toxicity }\end{array}$ \\
\hline Cramer et al. [4] & $\begin{array}{l}\text { Bexarotene/ } \\
\text { Targretin in } \\
\text { DMSO or } \\
\text { micronized in } \\
\text { water }\end{array}$ & $\begin{array}{l}3 \text { to } \\
14 \text { days } \\
\text { and } \\
3 \text { months }\end{array}$ & Increase & $\begin{array}{l}\text { Decrease of } \\
A \beta 40 \text { or } A \beta 42 \\
>25 \%\end{array}$ & $\begin{array}{l}\text { Repeated dosing of } \\
3 \text { to } 14 \text { days } \\
\text { decreases } A \beta \\
\text { deposits by } 30 \text { to } \\
75 \% \text {; } 3 \text {-month } \\
\text { treatment had no } \\
\text { effects }\end{array}$ & $\begin{array}{l}\text { Improved } \\
\text { context- } \\
\text { dependent fear } \\
\text { memory. } \\
\text { Improved spatial } \\
\text { memory. } \\
\text { Improved social } \\
\text { behavior }\end{array}$ & $\begin{array}{l}\text { Unclear } \\
\text { whether } \\
\text { different } \\
\text { from } \\
\text { control }\end{array}$ & NR \\
\hline Price et al. [9] & $\begin{array}{l}\text { Bexarotene in } \\
\text { solutol:ethanol: } \\
\text { water } \\
(15: 10: 75)\end{array}$ & $\begin{array}{l}3 \text { to } \\
7 \text { days }\end{array}$ & Increase & No effect & No effect & NR & NR & $\begin{array}{l}\text { Increased liver } \\
\text { weight }\end{array}$ \\
\hline Fitz et al. [11] & $\begin{array}{l}\text { Targretin in } \\
\text { glycerol }\end{array}$ & 15 days & Increase & $\begin{array}{l}\text { Decrease of ISF } \\
\text { Aß40 and } \\
\text { A } 42 \text { by } 23 \text { to } \\
26 \% \text {; no effect } \\
\text { on extracted } \\
\text { soluble } A \beta\end{array}$ & No effect & $\begin{array}{l}\text { Improved spatial } \\
\text { memory. } \\
\text { Improved long- } \\
\text { term memory }\end{array}$ & NR & NR \\
\hline $\begin{array}{l}\text { Veeraraghavalu } \\
\text { et al. [7] }\end{array}$ & $\begin{array}{l}\text { Targretin in } \\
\text { DMSO:ethanol: } \\
\text { sunflower oil } \\
(6.6 \%: 4 \%: 89.6 \%)\end{array}$ & 7 days & Increase & Small effects & No effect & NR & No effect & NR \\
\hline $\begin{array}{l}\text { Tesseur et al. } \\
\text { [8] }\end{array}$ & $\begin{array}{l}\text { Bexarotene in } \\
\text { Captisol and } \\
\text { HP- } \beta-C D / \\
\text { Tween }\end{array}$ & 19 days & Increase & No effect & No effect & $\begin{array}{l}\text { Unclear effect on } \\
\text { social recognition } \\
\text { memory and fear } \\
\text { memory }\end{array}$ & NR. & $\begin{array}{l}\text { Loss of body } \\
\text { weight, } \\
\text { irritation and } \\
\text { breathing } \\
\text { problems, } \\
\text { increased } \\
\text { grooming }\end{array}$ \\
\hline $\begin{array}{l}\text { LaClair et al. } \\
{[10]}\end{array}$ & $\begin{array}{l}\text { Bexarotene in } \\
\text { DMSO or corn } \\
\text { oil }\end{array}$ & $\begin{array}{l}3 \text { to } \\
14 \text { days }\end{array}$ & Increase & NR & No effect & $\begin{array}{l}\text { No effect on } \\
\text { context- or } \\
\text { conditioned } \\
\text { stimulus- } \\
\text { dependent fear } \\
\text { memory }\end{array}$ & No effect & NR \\
\hline Ulrich et al. [12] & $\begin{array}{l}\text { Targretin in } \\
\text { water }\end{array}$ & 36 hours & Increase & $\begin{array}{l}\text { Decrease of ISF } \\
\text { A } 40 \text { by } 45 \%\end{array}$ & NR & NR & NR & NR \\
\hline
\end{tabular}

$\mathrm{A} \beta$, amyloid beta; ApoE, apolipoprotein $\mathrm{E}$; DMSO, dimethyl sulfoxide; HP- $\beta$-CD, 2-hydroxypropyl- $\beta$-cyclodextrin; ISF, interstitial fluid; NR, not reported.

contrast to the bulk of their results, Cramer and colleagues reported that, after chronic daily bexarotene treatment for 3 months, they could not find a decrease in $A \beta$ deposits, despite reduced soluble $A \beta$ levels and target engagement [4]. This result is puzzling compared to the rest of their results and no clear explanation for this discrepancy is given. The other claims of the publication were, optimistically speaking, confirmed by some groups and not by others. For instance, three groups found lowering of soluble $A \beta$ levels in interstitial fluid $[11,12]$ or in brain extracts [7], whereas three groups found no effects $[8,9,11]$. From Table 1 it becomes clear that the formulation of bexarotene might be very critical in this regard. The groups who observed an effect used
Targretin for their mice. Targretin is the commercial formulation of bexarotene and contains a lot of additional 'stuff' (see detailed component list in [13]). This raises the question of whether those additional components could affect the results, especially since the bexarotene formulations used by the other groups resulted in efficient brain exposure as well, precluding the lack of target engagement as an explanation for this discrepancy. The original publication by Cramer and colleagues [4] mentioned the use of Targretin in some experiments and of bexarotene powder (in water or DMSO) in other experiments, explaining some of the confusion in the follow-up studies. The authors [14] indicated afterwards that they actually used Targretin for their dosing studies 
[4] but it remains to be fully clarified what was exactly used in the different experiments of the original work [4].

The behavioral data analyzing the effects of bexarotene on cognition and memory, which are crucial for the clinic, are the most difficult and most controversial to interpret. Cramer and colleagues [4] claimed that bexarotene significantly improved spatial and fear memory in their mice. Improvement in spatial memory upon bexarotene treatment was reproduced in one follow-up study [11], but improvement of fear memory could not be reproduced [10] or was reported to be inconclusive in a third study [8]. The latter study, although inconclusive, is quite informative from another perspective. Indeed, these authors reported a series of confounding effects in the mice treated with the drug - that is, severe loss of total body weight, breathing problems, and increased grooming - indicating that the mice felt rather uncomfortable and might even suffer from the treatment [8]. Although the authors of the Cramer and colleagues' study interpreted the behavioral data of the latter study in their response-comment as confirmative of their original data [14], the authors of the latter study were much less positive and indicated that the animals might have been too sick to allow any confirmative conclusions [8]. In addition to these side effects, Price and colleagues [9] reported evidence that bexarotene significantly increased liver weight in treated mice, indicating liver steatosis.

FDA files report that bexarotene induces severe upregulation of triglyceride and total cholesterol levels in many patients, and high-density lipoprotein cholesterol is lowered in $25 \%$ of treated patients [5]. As the dyslipidemia is reversible after stopping the treatment, this may not pose major issues when treating cancer patients for a limited time. However, AD patients at risk might need treatment for many years, and in such cases the dyslipidemia would become chronic and could seriously compromise cardiovascular health.

Finally, the original publication of Cramer and colleagues [4] claimed a significant upregulation of microglial activation in bexarotene-treated animals. However, some control stainings and quantifications were lacking in the manuscript, making it difficult to ascertain how definitive these observations were. Indeed, two independent follow-up studies did not see effects on microglia activation $[7,10]$.

\section{Conclusion}

Collectively, the above summarized data neither support nor contradict the hypothesis that apoE4 fails to protect against $\mathrm{AD}$ and the question is still open. It is clear that the original data published by Cramer and colleagues [4] were interpreted with a lot of optimism, which is understandable given the huge unmet needs in the field. Given the central role of apoE4 in the risk for $\mathrm{AD}$, the proposed approach remains potentially interesting. For the time being, however, we strongly suggest that researchers and clinicians interested in this work perform their own additional preclinical validation before starting clinical trials with bexarotene in humans. In addition, given the reported side effects and possible risks, 'offcounter' use of Targretin by desperate $\mathrm{AD}$ patients should be tempered until all the raised issues have been sufficiently clarified.

\section{Abbreviations}

AD: Alzheimer's disease; apoE: Apolipoprotein E; AB: Amyloid beta; DMSO: Dimethyl sulfoxide; FDA: US Food and Drug Administration; RXR: Retinoid X receptor.

\section{Competing interests}

BDS is consultant for Janssen Pharmaceutica, Remynd NV and Envivo Pharmaceuticals.

\section{Acknowledgements}

This work was supported by the Fund for Scientific Research Flanders, the KU Leuven, a Methusalem grant from the KU Leuven and the Flemish government, the Foundation for Alzheimer Research (SAO/FRMA) to BDS. BDS is the Arthur Bax and Anna Vanluffelen chair for Alzheimer's disease.

Published: 7 November 2013

\section{References}

1. Sharifov OF, Nayyar G, Garber DW, Handattu SP, Mishra VK, Goldberg D, Anantharamaiah GM, Gupta H: Apolipoprotein E mimetics and cholesterol-lowering properties. Am J Cardiovasc Drugs 2011, 11:371-381.

2. Mahley RW, Huang Y: Apolipoprotein E sets the stage: response to injury triggers neuropathology. Neuron 2012, 76:871-885.

3. Liu CC, Kanekiyo T, Xu H, Bu G: Apolipoprotein E and Alzheimer disease: risk, mechanisms and therapy. Nat Rev Neurol 2013, 9:106-118.

4. Cramer PE, Cirrito JR, Wesson DW, Lee CY, Karlo JC, Zinn AE, Casali BT, Restivo JL, Goebel WD, James MJ, Brunden KR, Wilson DA, Landreth GE: ApoE-directed therapeutics rapidly clear beta-amyloid and reverse deficits in AD mouse models. Science 2012, 335:1503-1506.

5. FDA: Targretin Drug Approval Package. [http://www.accessdata.fda.gov/ drugsatfda_docs/nda/99/21055_Targretin.cfm].

6. Lalloyer F, Pedersen TA, Gross B, Lestavel S, Yous S, Vallez E, Gustafsson JA, Mandrup S, Fiévet C, Staels B, Tailleux A: Rexinoid bexarotene modulates triglyceride but not cholesterol metabolism via gene-specific permissivity of the RXR/LXR heterodimer in the liver. Arterioscler Thromb Vasc Biol 2009, 29:1488-1495.

7. Veeraraghavalu K, Zhang C, Miller S, Hefendehl JK, Rajapaksha TW, Ulrich J, Jucker M, Holtzman DM, Tanzi RE, Vassar R, Sisodia SS: Comment on "ApoEdirected therapeutics rapidly clear beta-amyloid and reverse deficits in AD mouse models". Science 2013, 340:924-f.

8. Tesseur I, Lo AC, Roberfroid A, Dietvorst S, Van Broeck B, Borgers M, Gijsen H, Moechars D, Mercken M, Kemp J, D'Hooge R, De Strooper B: Comment on "ApoE-directed therapeutics rapidly clear beta-amyloid and reverse deficits in AD mouse models". Science 2013, 340:924-e.

9. Price $A R, X u$ G, Siemienski ZB, Smithson LA, Borchelt DR, Golde TE, Felsenstein KM: Comment on "ApoE-directed therapeutics rapidly clear beta-amyloid and reverse deficits in AD mouse models". Science 2013, 340:924-d.

10. LaClair KD, Manaye KF, Lee DL, Allard JS, Savonenko AV, Troncoso JC, Wong PC: Correction: treatment with bexarotene, a compound that increases apolipoprotein-E, provides no cognitive benefit in mutant APP/PS1 mice. Mol Neurodegener 2013, 8:26.

11. Fitz NF, Cronican AA, Lefterov I, Koldamova R: Comment on "ApoEdirected therapeutics rapidly clear beta-amyloid and reverse deficits in AD mouse models". Science 2013, 340:924-c. 
12. Ulrich JD, Burchett JM, Restivo JL, Schuler DR, Verghese PB, Mahan TE, Landreth GE, Castellano JM, Jiang H, Cirrito JR, Holtzman DM: In vivo measurement of apolipoprotein $\mathrm{E}$ from the brain interstitial fluid using microdialysis. Mol Neurodegener 2013, 8:13.

13. Drugs.com: Targretin. [http://www.drugs.com/uk/targretin-capsules-1302. html].

14. Landreth GE, Cramer PE, Lakner MM, Cirrito JR, Wesson DW, Brunden KR, Wilson DA: Response to comments on "ApoE-directed therapeutics rapidly clear beta-amyloid and reverse deficits in AD mouse models". Science 2013, 340:924-g.

\section{doi:10.1186/alzrt218}

Cite this article as: Tesseur and De Strooper: When the dust settles: what did we learn from the bexarotene discussion? Alzheimer's Research \& Therapy 2013 5:54 